\title{
THE ROLE OF MODERN COMMUNICATION TECHNOLOGY IN THE INVENTION OF THE GEO - BODY OF SUNDANESE
}

\author{
Holy R. Dhona \\ Communication Department, Universitas Islam Indonesia
}

\begin{abstract}
This paper discusses how modern communication technology, introduced by colonial powers to Sundanese, transformed Sundanese spatiality mode from Mandala to a modern colonial spatiality. Sundanese is the second largest ethnic in Indonesia after Javanese. According to the modern account, Sundanese is the native of the western part of Java Island whereas Javanese is the native of the middle and eastern parts of the island. Many scholars in the field of Sundanese study argued that Sundanese identity, as opposed to Javanese identity, had been already formed in the pre-colonial Java. I challenge this notion by arguing that Sundanese identity was formed after Sundanese encountered modern knowledge of spatiality. Using Foucauldian genealogical analysis, I examine Sundanese newspapers in 1910s as well as colonial writings such as Raffles' History of Java. I argue that the transformation of spatiality from Mandala to colonial modern spatiality formed a new identity of Sundanese, a geo-body of Sundanese, which can also be seen as the birth of Sundanese as a distinguished ethnic category different from Javanese in the early 20th century. This modern spatiality introduced by the colonial powers and mediated by the modern form of communication technology
\end{abstract}

Keywords: colonialism, ethnicity, technology, geo-body of Sundanese

\section{INTRODUCTION}

Indonesia is a home for many of ethnic groups. According to the latest survey on Indonesia's ethnic group, there are almost 350 ethnic groups with different languages (Ananta, et all. 2013). In Indonesia, ethnicity is generally considered as an heritage from the ancestors. Therefore ethnicity is not to be related to Indonesian colonialized experience. The colonial effect to ethnicity is rarely discoursed, though colonialism and its communication technology had epistemological effect to the colonialized.

The island of Java is the heart of the Dutch colonial government. There are two large group of etnic in this island; the Javanese, who native to the middle and the eastern part of Java and the Sundanese who native to the western part of the island. Based on the lastest survey on ethnic group, the Javanese is the largest ethnic in Indonesia and the Sundanese is the second (ibid). Many scholars of Sundanese studies believe that Sundanese ethnicity was existed in the precolonial era and derived from Sundanese kingdom in the past. (Zimmer. 2002; Moriyama.2003; Ekadjati 2004). This paper rejects the identity of Sundanese ethnicity as a legacy of the past as argued. I argue that Sundanese identity as an ethnic group is the product of colonialism.

In this paper, I will explain that Sundanese identity, a feeling to have different identity from other ethnic especially Javanese in other part of Java Island, was product of European colonial's geographical imagination that always divides Java into two territories (Java and Sunda). This colonial's geographic imagination was negotiated among Sundanese, and became embodied when nationalism was introduced in the early 20th century.

In this embodiment process, there is role of modern communication technology as stated in Benedict

Coressponding Author: holy.rafika@gmail.com 
Anderson's imagined community concept. Anderson (1983) put the imprint capitalism as central element in the formation of nation. In the field of communication/media theory, Innis (2008) stated that the paper and printing industries supported the development of monopolies of space in nationalism and the state.

I use the term of 'modern communication technology' to emphasizes the 'modern' that simply means "after the pre-modern". Hence, what I refer as the "modern communication technology" is not only printed media but also a new mode of language. Language contructs the subject, therefore the tranformation of mode of language means the tranformation of subject. By this approach, I emphasize that the effect of communication technology is not only a transformation of communication medium, but also an epistemological transformation of subject.

I will rely on genealogy, a method popularized by Michel Foucault. Foucault (1980) wrote that "Genealogy returns to the three modalities of history that Nietzsche recognized in $1874 \ldots$ (but) they are metamorphosized; the veneration of monuments becomes parody, the respect of ancient continuities becomes systematic dissociation, the critique of the injustice of the past by a truth held by men in the prasent becomes the destruction of the man who maintains knowledge by the injustice proper to the will to knowledge". I will put simply genealogy, in my research problem, as the systematic dissociation of ancient continuity of Sundanese. By this perspectif, I argue that Sundanese modern identity is based on mode of spatiality that introduced by colonial order, rather than the continuity of Sundanese ancestors.

\section{Ethnicity in Indonesia as product of colonialism}

Ethnicity usually translated as the classification of person or group relationships (Eriksen. 2010). In Indonesia, ethnic groups usually refer to the specific cultural group known as 'suku bangsa'. Since Indonesia only has a single nationality, the 'Suku bangsa' means groups/communities have become a part of the Indonesian nationality. Sometimes the use of the ethnicity's term refers to 'race', for example the Chinese ethnic in Indonesia.
The best summary of ethnicity in Indonesia was written by Gerry Van Klinken (2003). Drawing on Weberian definition on ethnicity, Klinken argued that ethnicity in Indonesia is merely about politic. Though he defines ethnicity as "..a belief in common ancestry and memories of a shared historial past, and stressed the notion of kinship. People feel comfortable in ethnic group because it seems family to them. It listed a range of other caracteristics, including language and religion" (Klinken. 2003; p.73), Klinken insist that, "...ethnicity was derived from politics, and not politics from ethnicity".

According to Klinken, the ethnicity is always a political matter. I agree with it, eventhough Klinken did not discuss further about how the colonialism constituted ethnicity as the identity in Indonesia. This paper argues the colonialism, a very important factor in Indonesian's ethnic groups formation as happen in South East Asia.

I owed much to Andaya (2008) who stated that British colonialism started to construct the Malay identity through territorialization under the political leadership in ethnicity formation in Malaka Strait. This political leadership was formed with the language, customs and even the ' characters' that are considered as a single identity in Malay (Andaya. 2008: 237). On Javanese subject, Pemberton (1999) argued that Javanese identity was constructed during colonial order in Java Island. The Dutch was invented Solo or Surakarta, the oldest Javanese court, as a 'truly Javanese', wherefrom the Javanese identity was identified till now.

There are many ethnicity studies in Indonesia. Klinken sees ethnicity as a specific and isolated cultural product. In the same way, with addition in emphasizing linguistic factor, Zane Goebel (2013) stated that ethnicity in Indonesia is discussed in terms of language. Goebel critizised this simplification and argued that ethnic groups in Indonesia were emerged because of many causes in their history and not only the different of language.

As an addition to Goebel critic, I argue that relying Indonesian ethnicity on language will hide the colonial role as an ethnic inventor. In Sundanese ethnic identity case, many scholar relies on Sundanese language as the primary identity of 
Sundanese. The best figure I will explain here is Mikihiro Moriyama, the most prominent scholar in Sundanese studies,

Struggling in the field of literary history, Moriyama (2003) stated that Sundanese language, was found and created by colonial. Building a comfort base on the Sundanese language analyzing, Moriyama simply concluded that the consciousness of being Sunda existed before the colonial era. He wrote former Sundanese language natives seems has awareness that they differ from the Javanese native. The existence of two old kingdom, Majapahit and Sunda was the source for the two ethnic identity in Java.

According to Moriyama, the role of colonialism was only to affirmed Sundanese ethnic identity by the invention of Sundanese modern language. The Sundanese ethnicity, therefore, was not the product of colonial era, it was a continuity from the kingdom of Sundanese where the Sundanese language was existed and used.

I have two point to critized Moriyama's argument. First, the Sundanese identity was not privilege for they who speak with Sundanese language in the early 20th century. Who speak the other language as long as they are native to region that called by 'Sunda region' was also defined as Sundanese. For example, the peoples in the region in Cirebon and Banten who speak Javanese were categorized as Sundanese people. In the modern era, the Sundanese encyclopedia (Rosidi, Ajip et all.2000), the formal text about Sundanese culture, was named the other culture with other language as part of Sundanese culture in its entitle. Second, we can not simplify Majapahit Kingdom as Javanese and so Padjadjaran Kingdom as Sundanese.

\section{Sundanese ethnicity as a geo-body of nation}

Indonesian nationality, as described by Olsen (2008), is a new discourse that compete and dominate then to the discourse of other nationality forms in early 20th century. This era called the 'proto-nationalism' era by some scholars. In the early 20th century, when Indonesia has not existed yet, there are many nationality in the Dutch Indie; Javanese, Ambonese, Minangese, Sundanese and others. In the early 1920th, these nationalities probably changed gradually to be an ethnic groups,'suku-suku bangsa'. In the other word, these nationalites were excluded when "...the youngsters of those days signaled their regional origins not in the name of separatist local nationalisms, but in their committing of these regional origins to a colony-wide joint and common project of liberation. They paid no mind to the fact that Acehnese kings had once "colonized" the coastal regions of Minangkabau, that Buginese kings had enslaved Torajanese hillpeople, that Javanese aristocrats had tried to subjugate the Sunda highlands, or that Balinese overlords had successfully conquered the island of the Sasak" (Anderson. B.R.O. 1999)

So there is ever Sundanese nationality in early 20th century. Sundanese is not an ethnic group, but born as a nation. When Indonesia accepted as a nation to the whole of Dutch Indies people, the nationality of Sundanese was excluded, but the Sundanese awareness that differs from the others is still accommodated.

Hence, I will read Sundanese ethnic as Sundanese nation. I may put the concept of 'the geo-body of nation', a concept coined by Thongchai Winichakul (1994) to read the Sundanese ethnic identity. Thongchai saw the problem of nationalism is not only based on how one nation creates its region, but also how the 'nationhood' was formed by demarcated bodies in a particular region. In other word, the limit of nation is its spatiality.

In Southeast Asia, the concept of geo-body of nation that concern to the development of modern geographical knowledge among natives is usefull to look for the formation of nation. As Wolters (1999) stated, Mandala polity used in Southeast Asia, in which territory is not merely important to define self's boundary or self identity.

Furthermore, Thongchai found that Thailand nationalism grown with the transformation of Thai's spatiality. The old spatiality, in which the territory is not important than the traditional ruler, was replaced by the rigorous territorial boundaries as a sign to the emergence of a modern geographic region knowledge. The modern geographical spatiality becomes embodied in Thai Society through a geobody of the nation (Thongchai, W. 1994, p. 17) that is "a man-made definite territory which has effect to 
people and thing and also their relationship to classification, communication and continuous reinforcement".

According to Thongchai, relying the formation of nationality on its constituent elements (eg, language) will ignore the limits of that identity. Thongchai claimed that the spatial perspective which he offered is seeking to explain how the construction of a significant element, in which all of the nation's identity begins and ends. This significant element, as stated by Thongchai, is a territory.

\section{The Emergence of Sundanese Territory}

Sundanese scholar, Atja \& Danasasmita (1981, p. 62) argued that the concept of power among Sundanese in precolonial era was not based on territory. They argued that the polity in Sundanese was based on amount of 'manarekha', the term derived from Sanskrit (mana: to think; to predict; to count, and rekha; to note). This concept of manareka is identically with the concept of 'cacah' in Java. Cacah or manarekha is the unit to call 'house', the subject of land tax. The one 'house' in cacah is not a 'nuclear family', but can reach 40 to 50 peoples (Niel. et all. 2003, p. 209-211; see also Boomgaard. 2004, p. 354 ; Raffles. 1830, p. 69). For simply saying, the territory was not recognized by Sundanese as unit of power in the pre-colonial era. The concept of power in Sundanese was defined based on a body or a person.

Wolters (1982) suggested that the territory, as a unit of political power, in mandala polity is not something fixed. Hence, it is problematic to presuppose Sundanese and Javanese kingdom to have a fixed geographical boundary as Moriyama thought.

After the publishing of The History of Java, a monumental book written by Thomas Stanford Raffles, the traditional polity in Java island was changed gradually. Raffles, EIC governor for East Indies, was inspired by Decada, the book authored by Portuguese writer Joao de Barros. Barros state "The land of Java we consider as two islands, whose position is from east to west,.... The javans themselves do not divide the land into two islands, but consider the whole length as constituting only one..." ( Quoted in Raffles, 1830, p. xv)
Inspired by Barros, Raffles convinced that the past of Java administration consists of two parts, east and west, where 'Javanese' is resident in the eastern part of Java Island and Sundanese is resident in the western part. Raffles was defined this two native based on the 'nationality' in different language and culture (Raffles, 1830, p. 9)

Raffles' invention became the basis idea of many European in the afterwards period. The western part of Java no longer recognizable as Westernlanden, a category that relate to the unity of Java, but Sundalanden. For instance, In 1841 Sundanese dictionary published the first in Amsterdam, where Roorda, the most authoritative of Dutch East scholar writes Sundanese as Sundalanden (Moriyama, 2003, p. 24). In 1842, Wolter Robert Van Hoevel published the research on the difference between Javanese and Sundanese people or Sundanezen (ibid : 25).

Eventhough many Europeans treat Sundanese as particular groups that have fixed territory as boundary, the territory was not still considered as boundary for Sundanese subject untill the early 20th century. For example, Soeradiwidjaja, one of Sundanese writer in Papaes Nonoman (1914), wrote that a lot of Sundanese in the villages area still felt that they were ruled by Susuhunan Solo, a king in the Middle of Java, Solo (Soeradiwidjaja. 1914). Sundanese identity therefore was not based on their territory or language, as European imagined, but it still lied on ancient patrimonial identity by the relationship with the king.

\section{The Birth of The Geo-Body of The Sundanese}

The awareness of Sundanese about their identity appears when nationalism began echoed in the early 20th century. For this era, I analyzed the texts of Papaes Nonoman (1914-1920), a newspaper produced by Paguyuban Pasundan, Sundanese organization founded in 1913 (Ekadjati, Edi S. 2004). Like another newspapers in the Dutch East Indies, Sundanese writers in Papaes Nonoman seems more interested in the issue of the progress ('kemadjoean'). The calling to 'be progressed' was featured in every number of Papaes Nonoman.

'Being progress' here generally means 'being Dutch/Europe'. 'Government School' considered more important and useful than 'Islamic boarding school 
(pesantren)'. Doctor considered smarter than the quack (Koesoma Soedjana. 1915). European languages, especially the Dutch, was considered as the language of progress and hence Papaes Nonoman provide a rubric entitled "Diadjar basa Walanda teu make goeroe". This admiration to Dutch/Europe eliminated the Javanese then as 'the centre of progress' in the heart of Sundanese; Javanese is only 'Sundanese second teacher' after the Dutch.

Two points should be noted from this moment. First, in the vortex of the discourse of 'the progress', Sundanese found their 'nationalism' ('Nationaliteitsgevoel'). This form of nationalism effectively obscured the process imitation of they did. 'Being progress' which means 'being Dutch' are not considered imitate other culture, but it is obligation for the sake of 'nationalism' (Nationaliteitsgevoel) and 'patriotism' (Vaderlandsliefde) (Anon. 1914). So, 'being Dutch' is an attempt to be 'the true Sundanese'. Secondly, through the Nationaliteitsgevoel, Sundanese see themselves as 'nation', in a more specific way, a group that different from the other nation; Javanese nation.

Language has significant role in the formation of Sundanese nation. In these years, Javanese language was considered to dominate Sundanese language. On July 1st, 1914, Daeng Kanduruan Ardiwinata, the president of Paguyuban Pasundan wrote that Sundanese needs to purify their language by discarding the Javanese uptaking language from Sundanese language (Ardiwinata, D.K 1914a). He also suggested to all Sundanese writer to developed the prose, a modern form of literary that they studied from Dutch, as opposed to tembang, the old form of Sundanese literary that they learned from Javanese (Ardiwinata, D.K 1914c). Sundanese also tries to develop a Sundanese dictionary that represent Sundanese as a modern language. For this dictionary, they held a contest that published in Papaes Nonoman frequently.

The most interesting fact about the development of Sundanese language, for me, is its function as the 'instrument of geo-body of nation'. This means that the discourse of the language is not only point to specify Sundanese culture that differ from Javanese culture with language, but also an instrument to build a territorial border that separated from Javanese territorial.

By using the metaphor of the sea, in August 1914 Ardiwinata wrote the differences among Sundanese, Javanese and Malay languages. Sunda seems a strait that have an 'in between' position where Java and Malay has connected. (Ardiwinta, DK. 1914b). For me, this metaphor is not refer to the differences among these three cultures only, but it is a discourse about Sundanese border. Meanwhile, there is the Dutch colonial government regulation namely Reglement Sakola art. 6 stbl. 1893 No. 125 that instructs every schools to use a purest native language as the language of instruction. These courses of language eventually led Sundanese to determine their own territory, a 'Sundanese homeland'. The question is where is Sundanese border? Which school should use the purest native language of Sunda?

On March 7, 1915, a meeting set up by school teachers of Banten District held at Serang, Banten. This meeting makes a decision that Sunda region should be used the the main dialect/language (hooftdialect) that is Priangan/Eastern Priangan dialect which called 'Basa Priangan' (Ardiwinata, D.K. 1915). Meanwhile, the most important decision in this meeting, for me, is the decision about Sundanese region, where the purest language would be used. 'Sunda region' in that decision is Banten, Cirebon, Betawi and Priangan.

However, Djajadisastra, a Sundanese writer, did not agree with this Sunda-region. Djajadisastra considered Serang, a location where the hooftdialect decided, was not a part of the Sunda- in land. Therefore, according to Djajadisastra, the concensus on the main dialect of Sundanese is illegitimate (Djajadisastra. 1915). Though Djajadisastra criticism never get any response, his idea reflects how the important of Sundanese territoriality invention to the discourse on Sundanese language.

Furthermore, mentioning Sundanese regions as manifestated to the whole part of "Western Java" have been imagined by Raffles and other European in previous century. Ardiwinata wrote that people of Banten and Cirebon must learn 'Eastern Priangan Dialect' in the name of Sundanese nationalism (Ardiwinata, D.K. 1915). Eventhough the decision of 
meeting is limited to the school teacher, Ardiwinata suggest that the hoftdialect should be used everyday in Sundanese event, not limited at school. From this consensus, now, Java Island consisted of two cultures with two fixed territorial; Javanese and Sundanese. Nowadays, there is single Javanese that differs from Sundanese.

This idea of region in this era is very different from Sanghyang Siksakanda Ng Karesian, the old Sundanese text that written in 1512. Sanghyang Siksakanda $\mathrm{Ng}$ Karesian, considerd Java and Surabaya as two different region whose different languages (Atja \& Danasasmita 1981, p. 62). Surabaya now is the city which belong to East Java and considered as part of 'Java'. Therefore, Sanghyang Siksakanda did not treat 'Java' as a unity of the eastern and the middle part of Java Island as like as Sundanese modern treated Javanese.

\section{CONCLUSION}

Sundanese identity as an ethnic group is a product of colonialism. This identity is based on the colonial's geography imagination which divides Java Island into two parts of territories since 16th century. This modern geography then was negotiated among Sundanese and embodied when nationalism was discussed in the early 20th century. This form of modern spatiality suspends the old mode of spatiality when there are a lot of Sundanese who believe that their identity is rely on the king or patrimonial ruler.

I argue that the language discussed by Sundanese to distinguish their identity from Javanese in early 20th century was a field of the modern geographical knowledge. The language is a form of mutation from European ideas to divide the Java island's territory into two parts. For this purpose, the language formed as a modern communication technology, as it discussed in the relation for national identity. All this discourse distributed by Sundanese printed media, the Sundanese modern communication technology that rapidly grow up in early 20 th century.

\section{REFERENCES}

Ananta, Aris., Evi N.A., M Sairi H,, Nur B. H., Agus Pramono. 2013. Changing Ethnic Composition: Indonesia, 2000-2010. Proceeding of XXVII IUSSP International Population Conference, Busan, Korea, August
Andaya, L. Y. 2008. Leaves of the same tree: Trade and ethnicity in the Straits of Melaka. Honolulu: University of Hawai'i Press

Anderson, B. R. O. G. 1983. Imagined communities: Reflections on the origin and spread of nationalism. London, UK: Verso

Anderson, B. R. O. (1999). Indonesian nationalism today and in the future. Indonesia. April 1999, page 1-11.

Anonim. 1914. Pamanggihna Anoe Ngarang. Papaes Nonoman 31 March, page 5-6. Weltvreden

Ardiwinata, D.K., 1914a. Basa Djawa di Priangan. Papaes Nonoman 1st July, page 2-5. Weltvreden

Ardiwinata, D.K. 1914b. Doea Sagara Noe Teu Katembong. Papaes Nonoman 1st August, page 2-3. Weltvreden

Ardiwinata, D.K. 1914c. Proza en Poezie. Papaes Nonoman, 1st Oktober, page 3-5. Weltvreden

Ardiwinata, D.K. 1915. Basa Soenda Mana Anoe Koedoe Dipake. Papaes Nonoman 31 August. Weltvreden

ATJA and DANASASMITA, SALEH 1981.Sanghyang Siksakanda Ng Karesian; Naskah Sunda Kuno Tahun 1518 Masehi. Proyek Pengembangan Permuseuman Jawa Barat.

Djajadisastra.1915. Kikintoen ti Pagoenoengan. Papaes Nonoman 30 April, page 4. Weltvreden

Ekadjati, E.S. 2004 Kebangkitan Kembali Orang Sunda: Kasus Paguyuban Pasundan 1913-1918. Bandung, Indonesia: Kiblat Buku Utama

Elson, R. E. 2008. The idea of Indonesia: a history. Cambridge, UK, Cambridge University Press.

Eriksen, T. H. 2010. Ethnicity and nationalism: anthropological perspectives. London, Pluto Press

Foucault, M. (1980). Language, counter-memory, practice: Selected essays and interviews. Ithaca, N.Y: Cornell University Press.

Goebel, Z. 2013. The idea of ethnicity in Indonesia. Tilburg Papers in Culture Studies, Working Paper Number 72.

Innis, H. A. 2008. The bias of communication. Toronto [Ont.], University of Toronto Press. http://www.deslibris.ca/ID/428449.

Klinken, Gerry Van. 2003. Ethnicity in Indonesia. In Ethnicity in Asia, edited by Collin Mackeras. London: Routledge Curzon, pp 64-87

Moriyama, M. 2003. Semangat Baru : Kolonialisme, Budaya Cetak, dan Kesusastraan Sunda Abad 19. Jakarta, Indonesia: Kepustakaan Populer Gramedia

Niel R., Hardoyo, Mun'im, D. Z. A., And Kartodirdjo, S. 2003. Sistem tanam paksa di Jawa: Kumpulan tulisan Jakarta: Pustaka LP3ES Indonesia : Pusat Perbukuan.

Pemberton, J. 2000. Jawa : On The Subject of Java. Yogyakarta, Indonesia: Matabangsa

Raffles, T. S. 1830. The History of Java: 2 Volume. London: Black.

Rosidi, Ajip et all. 2000. Ensiklopedi Sunda: Alam, Manusia dan Budaya Termasuk Budaya Cirebon dan Betawi. (Jakarta. Indonesia; Dunia Pustaka Jaya). 
Thongchai, W. 1994. Siam mapped: A history of the geobody of a nation.

Honolulu: University of Hawaii Press.

Wolters, O. W. 1982. History, culture, and region in Southeast Asian perspectives. Singapore: Institute of Southeast Asian Studies.
Zimmer B.G., 2002. Linguistic Imaginations of The Indian Ocean World : Historial Viewpoints from Western Java, Proceeding of International Conference on Cultural Exchange and Transformation in the Indian Ocean world, University of California, Los Angeles. April 